\title{
Could Protected Areas in Brazil's Semi-Arid Conserve Endangered Birds Facing Climatic and Land Cover Changes?
}

\author{
Tiago Castro Silva ${ }^{1}$, Lara Gomes Côrtes ${ }^{1} \&$ Marinez Ferreira de Siqueira ${ }^{2}$
}

Recebido em 29/10/2019 - Aceito em 12/05/2020

\footnotetext{
1 Instituto Chico Mendes de Conservação da Biodiversidade, Brasil. <tiago-castro.silva@icmbio.gov.br, lara.cortes@icmbio.gov.br>.

2 Instituto de Pesquisa Jardim Botânico do Rio de Janeiro/JBRJ, Rio de Janeiro/RJ, Brasil. CEP: 22.460-000. < marinez@jbrj.gov.br> .
}

\begin{abstract}
Protected areas act as pillars on which conservation strategies are built. Besides human activities, global climate changes are an additional concern to species' conservation. In northeastern Brazil, climate change should lead to a replacement of the current native vegetation by semi-desert vegetation. This study evaluates whether the protected areas of the Caatinga can contribute to the maintenance of suitable climatic conditions for endangered birds over time in the face of global climate changes and land cover change. We used ecological niche models as input layers in a spatial prioritization program, in which stability indices were used to weight the targets. Results predicted that most taxa (18) will have their suitability lowered in the future, and all taxa (23) will have their ecological niche geographically displaced. However, our results showed that the Caatinga's protected areas system integrated with a set of priority areas can maintain suitable climatic conditions for endangered birds in the face of climate change and land cover change. On average, Caatinga's protected areas system could protect climatic stability areas at least 1.7 times greater than the scenarios without it. This reinforces the importance of protected areas as a biodiversity conservation strategy.
\end{abstract}

Keywords: Ecological niche models; spatial prioritization; Caatinga.

\section{As Áreas Protegidas no Semiárido do Brasil Podem Conservar Aves Ameaçadas de Extinção Diante de Mudanças Climáticas e de Cobertura da Terra?}

RESUMO - As unidades de conservação funcionam como pilares sobre os quais as estratégias de conservação são construídas. Além das ameaças diretas à biodiversidade causadas pelas atividades antrópicas, as mudanças climáticas previstas pelo Painel Intergovernamental em Mudanças Climáticas se configuram como outra preocupação à conservação das espécies. No nordeste do Brasil, as mudanças climáticas devem provocar a substituição da vegetação nativa atual por um semideserto. Este trabalho tem como objetivo avaliar se as áreas protegidas da Caatinga podem contribuir para a manutenção das condições climáticas adequadas para que os táxons de aves ameaçadas persistam ao longo do tempo diante das mudanças climáticas e ameaças antrópicas. Para tanto, utilizamos modelos de nicho ecológico como camadas de entrada em um programa de priorização espacial, no qual índices de estabilidade foram usados para dar pesos aos alvos. Os resultados preveem que, no futuro, a maioria dos táxons (18) terão a adequabilidade reduzida, e que todos os táxons (23) terão um deslocamento geográfico do seu nicho ecológico. Entretanto, o sistema de áreas protegidas da Caatinga, integrado a um conjunto de área prioritárias, pode manter as condições climáticas adequadas para que os táxons de aves ameaçadas persistam ao longo do tempo diante das mudanças climáticas e das ameaças antrópicas. Em média, em cenários futuros, o sistema de áreas protegidas da Caatinga pode proteger 1,7 vez mais áreas de refúgios climáticos do que quando está ausente. Isso reforça a importância do sistema de unidades de conservação como uma estratégia nacional de conservação da biodiversidade.

Palavras-chave: Modelos de nicho ecológico; priorização espacial; Caatinga. 


\title{
¿Podrían las Áreas Protegidas en las Zonas Semiáridas de Brasil Conservar las Aves en Peligro de Extinción que Enfrentan Cambios Climáticos y de Cobertura de la Tierra?
}

\begin{abstract}
RESUMEN - Las áreas protegidas actúan como pilares sobre los cuales se construyen las estrategias de conservación. Además de las actividades humanas, los cambios climáticos globales son una preocupación adicional para la conservación de las especies. En el noreste de Brasil, el cambio climático debería conducir a un reemplazo de la vegetación nativa actual por vegetación semidesértica. Este estudio evalúa si las áreas protegidas de Caatinga pueden contribuir al mantenimiento de condiciones climáticas adecuadas para las aves en peligro de extinción a lo largo del tiempo frente a los cambios climáticos globales y el cambio de la cubierta terrestre. Utilizamos modelos de nicho ecológicos como capas de entrada en un programa de priorización espacial, en el que se utilizaron índices de estabilidad para ponderar los objetivos. Los resultados pronosticaron que la mayoría de los taxa (18) tendrán su idoneidad reducida en el futuro, y todos los taxa (23) tendrán su nicho ecológico desplazado geográficamente. Sin embargo, nuestros resultados mostraron que el sistema de áreas protegidas de Caatinga integrado con un conjunto de áreas prioritarias puede mantener condiciones climáticas adecuadas para las aves en peligro de extinción ante el cambio climático y el cambio de la cubierta terrestre. En promedio, el sistema de áreas protegidas de Caatinga podría proteger las áreas de estabilidad climática al menos 1.7 veces mayor que los escenarios sin ella. Esto refuerza la importancia de las áreas protegidas como estrategia de conservación de la biodiversidad.
\end{abstract}

Palabras clave: Modelos de nicho ecológico; priorización espacial; Caatinga.

\section{Introduction}

Protected areas are usually established in order to maintain representative and viable samples of biodiversity that are protected from human impacts. However, this goal must be accomplished with regards to the limits imposed by the increasing human population, which require more space and natural resources (Margules \& Pressey 2000).

Beyond direct threats to biodiversity caused by human activities, climate changes, summarized by the Intergovernmental Panel on Climate Change, are considered as an additional concern to species conservation (Root et al. 2003). On a regional to global scale, the climate has a major influence on the species distribution (Pearson \& Dawson 2003). This influence can force species to shift their distribution horizontally and/or vertically, towards most suitable places, according to their metabolic temperature tolerance (Root et al. 2003). This shift follows the principles of niche conservatism theory, which proposes that species tend to change their geographical distribution in the face of global warming while searching for their original climate regime (Wiens \& Graham 2005). However, if the speed of climate change is higher than the ability of the species to adapt or change their distribution, they will face extinction (Wiens \& Graham 2005).
The fifth report of the Intergovernmental Panel on Climate Change indicates a reduction of up to $22 \%$ in precipitation in northeastern Brazil by 2100 (Magrin et al. 2014). Increases in temperature and water stress are also expected, along with long periods of drought in the second half of the 21st century (Marengo \& Bernasconi 2015). In the Caatinga, climate change is expected to lead to a replacement of the current native semi-arid vegetation by semi-desert vegetation (Oyama \& Nobre 2003).

Originally, Caatinga covered $10 \%$ of the Brazilian territory, but $46 \%$ of this area has already been converted (MMA 2011). Despite being the least known biome of Brazil, in terms of biological inventories numbers, it is the most biodiverse semiarid biome in the world (MMA 2002). Caatinga is an endemic ecosystem of Brazil, composed of a mosaic of dry forests and shrub vegetation (savannah-steppe), with humid montane forests and savannahs enclaves (Tabarelli \& Silva 2003). These enclaves are important components of landscape mosaic of Caatinga and play an important role maintaining ecological processes and species adapted to their conditions (Silva et al. 2003). Some species even migrate to humid areas during long droughts periods then come back to semiarid regions at rainy season (Silva et al. 2003). Therefore humid montane forests and savannahs 
enclaves, as their species, should not be treated apart from Caatinga once they are part of it (Silva et al. 2003).

Brazilian environmental law (MMA 2014a, 2014b) lists the countries' threatened fauna. From a total of 1173 endangered species, 234 are birds, 23 of which occur in the Caatinga. According to the National Action Plan for the Conservation of Birds of the Caatinga, the main threats to these species are habitat loss by fires, illegal charcoal production, replacement of native vegetation by pasture and agriculture, the capture of specimens for the wildlife trade, and illegal hunting (ICMBio 2014). Some species are further threatened by mining and uncontrolled tourism (ICMBio 2014).

In order to evaluate the impacts of climate change on biodiversity, ecological niche modeling has been applied on a large scale and for a variety of taxa (Araújo 2009, Wiens \& Graham 2005). This technique uses records of the current species distribution, combined with climatic variables, to assess the species-climate relationship, and then projects the distribution in areas that have a climate similar to the present one, based on future climate scenarios (Araújo 2009, Wiens \& Graham 2005).

Given the velocity of global climate change, many species will tend to respond by seeking to conserve their original climatic niche, rather than undergoing a rapid change in climate tolerance capacity (Parmesan \& Yohe 2003). It is important to identify and conserve regions considered as climatic stability areas, where the future components of biodiversity could remain even with climate change, and from where species will be able to expand again if future climatic conditions return to current patterns (Keppel et al. 2012). The identification of possible climatic stability areas can be accomplished through the intersection of present and future ecological niche modeling, if we assume the niche conservation for species in the future (Keppel et al. 2012). Climatic stability areas have the potential to provide the necessary conditions for the species to persist in the long term; thus, their incorporation in systematic conservation planning is of great value (Groves et al. 2012, Keppel et al. 2012).

Spatial prioritization can be used to assist in the development of systematic conservation planning related to species distribution, considering the current climate and future changes, in order to identify future climatic stability areas (Carrol et al. 2010, Lemes et al.
2013). These prioritization systems are essential to identify solutions that have the best cost and benefit, protecting the maximum of conservation targets with minimal protected area and minimizing land use conflicts.

The main goal of this paper is to analyze whether the current system of protected areas within the Caatinga can efficiently maintain suitable climatic conditions for its endangered birds over time, in face of global climate change and land cover change.

\section{Material and Methods}

\section{Occurrence records}

We selected 23 endangered birds taxa (MMA 2014a) that occur in the Caatinga, according to the National Center for Research and Conservation of Wild Birds (CEMAVE) (Table 1 Supplementary material). Some of these taxa do not occur in semi-arid zones but rather in enclaves of humid areas that are also part of Caatinga biome, therefore, were considered in this study.

The geographic coordinates of the occurrence records were compiled from workshops organized by the Chico Mendes Institute for Biodiversity Conservation (ICMBio), which have evaluated the conservation status, gathered all available information for threatened birdtaxa in Brazil and have subsidized the Brazilian list of threatened fauna (MMA 2014a). A search for occurrence records in the Global Biodiversity Information Facility (GBIF) and speciesLink databases was performed but did not return new records.

\section{Climatic variables}

Predictor variables were selected from 19 bioclimatic variables at 2.5 arc minutes spatial resolution, available from the Worldclim site (www.worldclim.org). Following Baselga \& Araújo (2009) and Nenzén \& Araújo (2011) , we used a Principal Component Analyses (PCA) and the Broken-stick method to select the variables that better explain the variability inside the multidimensional dataset. The first three-axis were chosen by the Broken-stick method. Together they explain $83 \%$ of the variance. The loading of each variable was calculated for the three axes, and the variable with the largest loading for each axis was selected: bio_11 (average temperature of the 
coldest quarter), bio_16 (precipitation of wettest quarter) and bio_19 (precipitation of the coldest quarter). These number of predictors also took into account the low sample size for some endangered species, to avoid over-fitting of the final model.

Among the various circulation models (GCMs), we chose HadGEM2-ES and CanESM2 because they perform well in the Brazilian northeastern (Cavalcanti \& Shimizu 2012, Silveira et al. 2013). We chose an intermediate scenario of greenhouse gas emissions, the Representative Concentration Pathways $4.5 \mathrm{~W} / \mathrm{m}^{2}$.

\section{Ecological niche modeling}

The ecological niche models were developed using the dismo package (Hijmans et al. 2013) built for $\mathrm{R}$ software (R Core Team 2015). The following algorithms implemented in this package were used: BIOCLIM (Booth et al. 2014), Generalized Linear Model (Madsen \& Thyregod 2011), Mahalanobis (Mahalanobis 1936, Rao 1973), Maxent (Phillips et al. 2006), Random Forest (Breiman 2001) and Support Vector Machine (Cortes \& Vapnik 1995). We chose at least one or two algorithms of each type (envelopes/distance, statistical inference and machine learning) so that all species had the chance to reach good models according to our exclusion criterion since the sample size varies for the endangered study species.

For evaluation, we used a k-fold cross-validation, with $\mathrm{k}=3$. For taxa with less than 10 records, we used the Jackknife approach $(\mathrm{k}=\mathrm{N})$. As a quantitative measure of performance, we used the True Skill Statistic (TSS). To generate binary models used in model evaluation we used the threshold that maximizes the sum of sensitivity and specificity (Liu et al. 2013). Models with TSS $>0.4$ were retained (Zhang et al. 2015) and used to generate final models, which were obtained by weighted mean by TSS values. Studies show that projections made by different algorithms can be so variable that it can compromise their usefulness for public policies (Araújo \& New 2007). To address this issue we took an ensemble approach in three steps by averaging final models of algorithms (Araújo \& New 2007, Kujala et al. 2013): 1) the ensemble by the algorithm was created by average weighted by the respective TSS (True Skill Statistic) values of the partitions of each algorithm, resulting in one final model by algorithm;2) the ensemble by species was created by performing a simple average between the final models of each algorithm, resulting in a final consensus model for each species for the present time and for each different GCM (Hadley Global Environment Model 2 - Earth Systemand Canadian Earth System Model 2); 3 ) the future models were created by performing a simple average between both future models, obtaining a single future model by species (Figure 1). This last consensus was created after a correlation test by species having as sample unit the values of the suitability of each cell. As the values did not present a normal distribution, even after an attempt of transformation by the square root of the sine arc, the Spearman correlation test was performed (on average $r=0.83$, $p$-value $<0.01$ ).

\section{Gain, loss and maintenance analysis}

In order to quantify the geographic displacement of ecological niches, we created a stability index based on the comparison of final binary ensemble models for both current and future models. By calculating the number of suitable pixels in the current and future models it was possible to evaluate lost and gained areas for each taxon, and also evaluate areas that will remain climatically adequate in the future. From these values, we calculated the stability index to identify those taxa that are predicted to suffer a great change in climatic suitability in the future. The stability index is the sum of the lost area ratio and the gained area ratio in the future, divided by two. Values closer to one imply expressive changes in the geographical area.

\section{Delta suitability}

We calculated the difference in the suitability of each taxon to identify those, within the Caatinga boundaries, that have a tendency to increase or decrease climatic suitability in the future. Therefore, we calculated the difference between the sum of future suitability values and the sum of the current suitability values. Thus, positive values of delta suitability indicate an increase in suitability in the future, and negative values represent a decrease.

\section{Spatial prioritization}

We used the Zonation software to classify the entire landscape by iteratively removing cells (pixels) of lower conservation value, in order to detect the best climatic areas for the target taxa in both current and future climatic conditions. After each removal, the conservation value for each pixel 


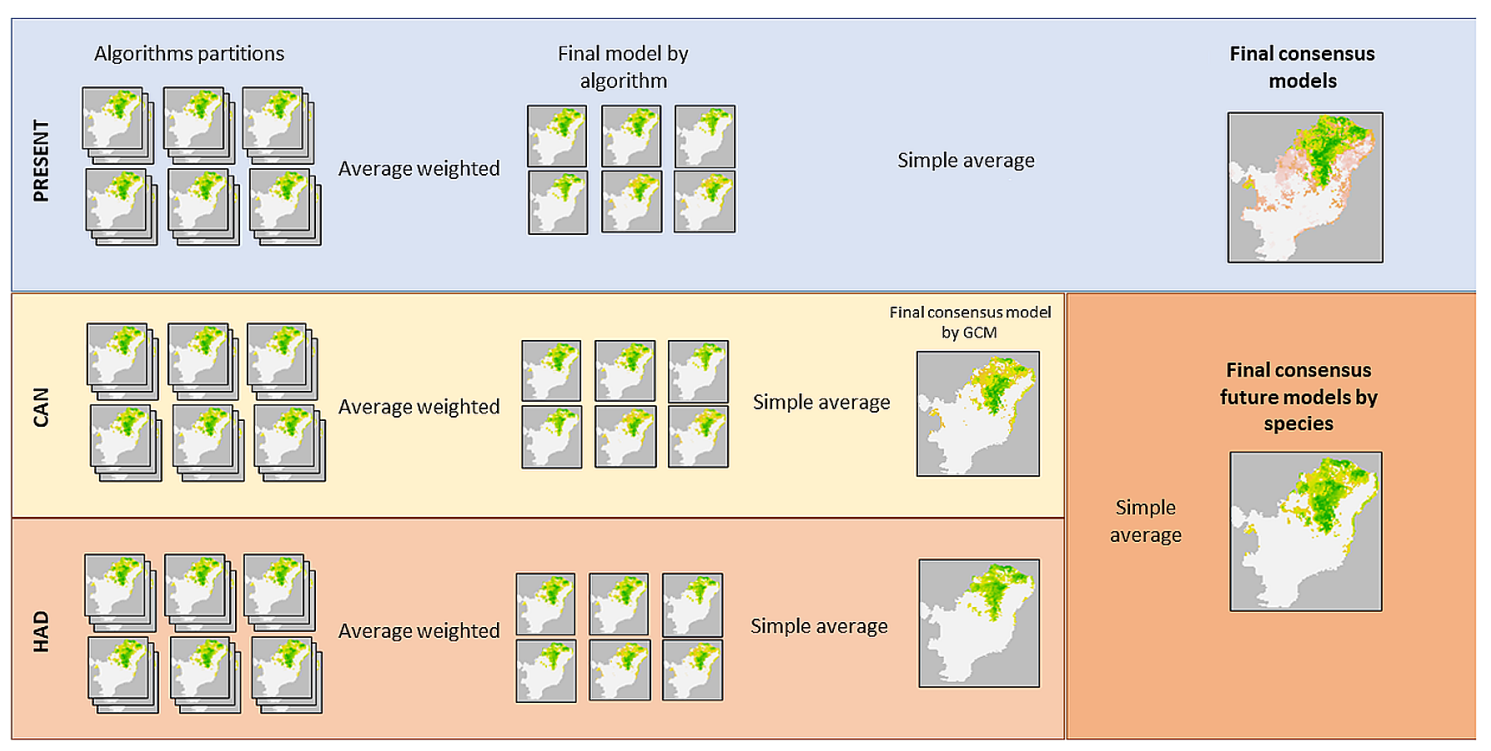

Figure 1 - Scheme of the production of ecological niche models. CAN stands for Canadian Earth System Model 2 and HAD stands for Hadley Global Environment Model 2 - Earth System.

is recalculated, and based on these new values the next pixel is removed. This process is repeated until all pixels are removed. The pixels removal order provides an idea of its importance; so that the later a pixel is removed, the more important it is. We chose the core-area removal rule, which tends to maintain the best distribution portions of each target until the end of the prioritization process, even for those common and widely distributed taxa (Moilanen et al. 2005).

At the ICMBio workshops to evaluate taxa's conservation status, fifteen sources of land cover change were identified (ICMBio 2018). There is spatial data available for nine of them: agriculture, livestock, forest fires, urbanization, hydroelectric, mining, highway, wind farms and human settlements. And, we found data of planned land cover change for agriculture, hydroelectric, mining, highway, and wind farms.

To proceed Zonation prioritization the taxa weights were determined by three attributes: (A) taxa's conservation status (MMA, 2014a) (Vulnerable $=1$, Endangered $=2$, and Critically Endangered $=3$ ), (B) Stability index and (C) Delta suitability. Weights were calculated as follows: Weight $=\mathrm{A}+\mathrm{B}+(1-\mathrm{C})$. All values of $\mathrm{A}, \mathrm{B}$, and $\mathrm{C}$ were standardized from 0 to 1 , giving more weight to more threatened taxa $(\mathrm{A})$, with the greatest geographical displacement of ecological niche (B), and with major habitat suitability loss in the future $(1-\mathrm{C})$.
Then, the weights of the land cover change layers (cost layers) were determined based on the frequency which they were cited in the taxa's profile systematized during ICMBio conservation status workshops: the more frequently a land cover change was cited, the more weight it had. These taxa's profile systematized were published in the Brazil's Red Book of Threatened Fauna (ICMBio 2018).

We used an uncertainty map layer distribution to account for uncertainty in biodiversity feature distribution data in conservation planning with Zonation. Thus, if more algorithms predict similar values of suitability, the standard deviation is smaller and, therefore, there is greater certainty about the value the pixel provides in the prioritizing process.

A landscape preservation condition layer was added to the prioritization process, reflecting the proportion of pixels occupied by natural vegetation. To build this layer we use the Brazilian Biomes Deforestation Monitoring Program (PMDBBS) data with deforestation until the year 2009 (MMA 2011).

The ecological interactions function allows for prioritizing of areas for species conservation by taking into account their current and future ecological niche models. This function creates an intersection layer between current and future models based on pixel values, the distance 
between the pixels, and the taxon dispersal ability, finding areas of climatic stability. Due to lack of specific information to each taxon about dispersion capacity and taking a conservative position, we assumed as a maximum dispersion ability as equal to alongside a pixel grid unity (i.e. 0.0417 degrees about $4.5 \mathrm{~km}$ at the equator).

We used watersheds as planning units, represented by sub-basins according to Brazilian National Water Agency (Pfafstetter 2012) This choice has ecological meaningful, as these limits have similar environmental characteristics inside, and allows for the sharing of the results with other conservation initiatives in the region. Using these planning units, the calculations of conservation value are performed considering all the pixels contained in the same planning unit, which are removed all at once (Moilanen et al. 2014).

The removal mask defines the order in which the sets of pixels should be analyzed and removed (Moilanen et al. 2014). When this technique is used, existing protected areas would be mandatorily present in the solution, as the goal is to select areas in addition to those that are already protected. At the time this study was carried out, Caatinga's protected area system covers $7,55 \%$ of the biome.

In this study, we adopted $17 \%$ of the most important pixels of the landscape as our solution goal, following the Aichi Biodiversity Target 11 of the Convention on Biological Diversity, which states that $17 \%$ of land area and inland waters should be conserved within protected areas systems.

We developed four scenarios in terms of the mandatory permanence of protected areas in the solution (removal mask), and the inclusion of existing and planned land cover change for this region as the cost. These scenarios allow us to assess the contribution of the existing protected areas system in maintaining appropriate climatic conditions to the target taxa: Scenario 1 (without removal mask and with existing cost), Scenario 2 (with removal mask and with existing cost), Scenario 3 (without removal mask and with existing and planned cost), Scenario 4 (with removal mask and with existing and planned cost).

Scenarios 3 and 4 differ from the previous ones by the inclusion of planned land cover change as cost prioritization. Our intention was to check whether the pattern of higher protection of target layers would remain when we include the existing protected areas system in the solution.

We evaluated scenario's performance using each taxon as replica, and performing a paired T-test in order to assess whether the difference between the averages (percentage of pixels values remaining in the solution) of the scenarios within each group of layers (current and future models, climatic stability areas layers, existing and planned land cover change layers) was significant.

\section{Results}

The ecological modeling process generated 486 models (for the 23 taxa analyzed), of which 439 (90\%) had a good performance (TSS > 0.8, $\mathrm{SD}=0.17$ ), the rest were discarded for the ensemble analysis (Supplementary Material - Figure 1).

The delta suitability index showed that most taxa (18) will lose suitability in future, and only five will have their suitability enhanced. Of those 18 taxa, three are predicted to lose suitability beyond the upper standard deviation limit of the mean: Augastes lumachella (au_lu), Crypturellus noctivagus zabele (cr_no_za) and Anodorhynchus leari (an_le) (Figure 2$)$.

Zonation algorithm provides the result in a percentage of the total area selection of each scenario of minimum, medium and maximum climatic suitability for each group of layers (Figure 3 and Table 2). Scenario 2 performance (including existing protected areas system) compared to Scenario 3 (without protected areas system) presented a higher percentage of the climatic stability areas of current ecological niche models and future models that are maintained in solution (Table 3). Scenario 2 with protected areas in the solution protect 1.7-times more suitability areas in future than Scenario 1, and 1.4-times more current and future models than Scenario 1; on the other hand, there was no difference in the existing land cover change between Scenarios 1 and 2 (Table 3).

As in Scenario 2, Scenario 4 was able to retain a higher percentage of the future stability areas. Scenario 4 protects 1.7 -times more future stability areas than Scenario 3, and 1.4-times more current and future models than Scenario 3. There was no difference in existing or planned land cover change between Scenarios 3 and 4 (Table 3). 


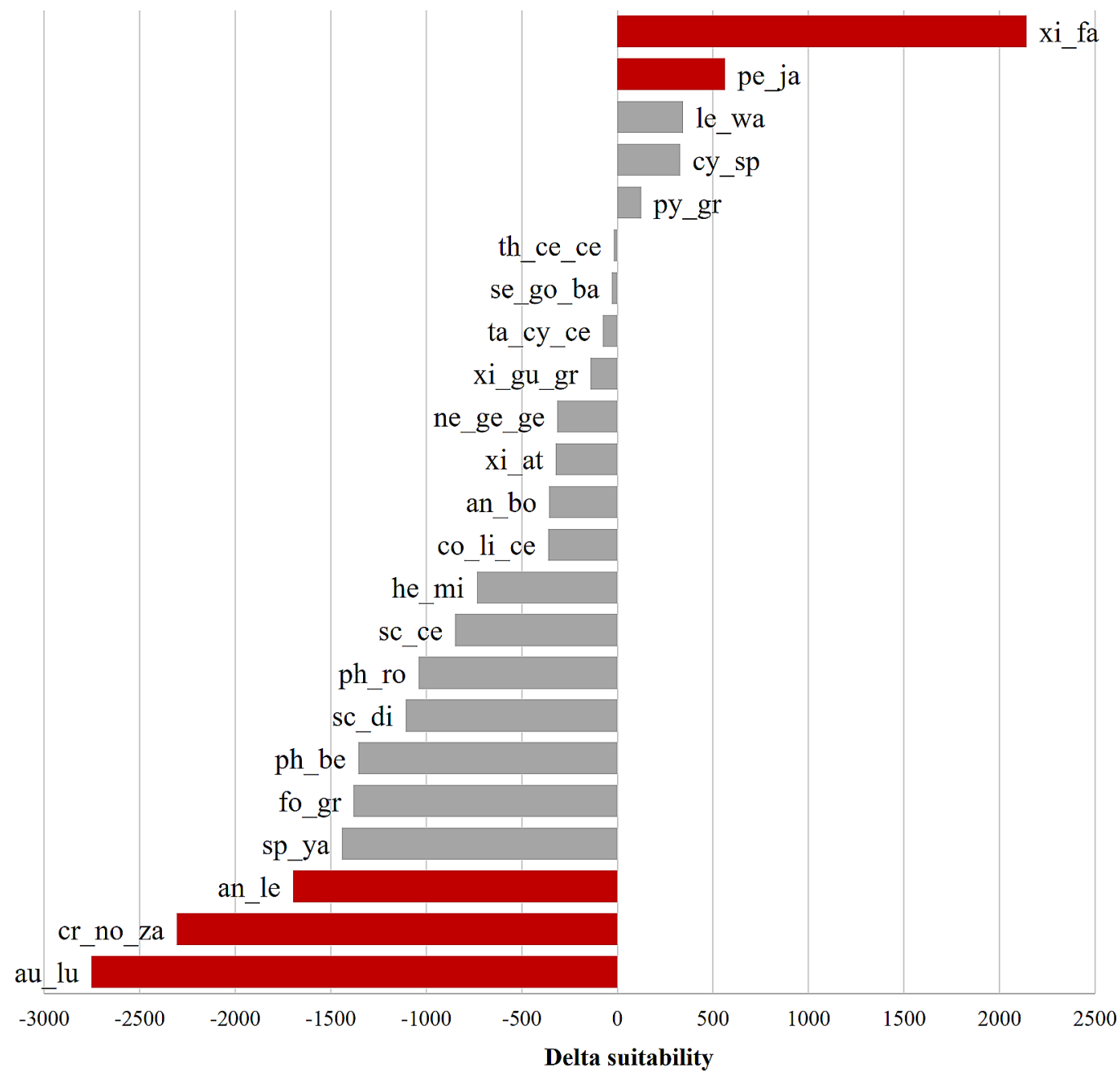

Figure 2 - Delta suitability for the 23 species of endangered birds. List of species at Supplementary Material.

Table 2 - Summary of the scenario performances, expressed as a percentage of pixels values remaining in the solution ( $17 \%$ of planning units). Minimum = minimum percentage remaining in the solution between the layers of the group; Mean = mean percentage remaining in the solution between the layers of the group; Maximum = maximum percentage remaining in the solution between the layers of the group; $\mathrm{NA}=$ not applicable.

\begin{tabular}{|c|c|c|c|c|c|c|c|c|c|c|c|c|c|c|c|}
\hline \multirow{3}{*}{\begin{tabular}{|l} 
Layers \\
Groups \\
Scenarios
\end{tabular}} & \multicolumn{3}{|c|}{$\begin{array}{c}\text { Climatic stability } \\
\text { areas }\end{array}$} & \multicolumn{3}{|c|}{ Current models } & \multicolumn{3}{|c|}{ Future models } & \multicolumn{3}{|c|}{$\begin{array}{l}\text { Existing land cover } \\
\text { change }\end{array}$} & \multicolumn{3}{|c|}{$\begin{array}{c}\text { Planned land cover } \\
\text { change }\end{array}$} \\
\hline & \multicolumn{3}{|c|}{$\mathbf{0}$} & \multicolumn{3}{|c|}{1} & \multicolumn{3}{|c|}{2} & \multicolumn{3}{|c|}{3} & \multicolumn{3}{|c|}{4} \\
\hline & Min. & Mean & Max. & Min. & Mean & Max. & Min. & Mean & Max. & Min. & Mean & Max. & Min. & Mean & Max. \\
\hline 1 & 1.8 & 23.3 & 49.5 & 1.4 & 10.4 & 18.1 & 4.7 & 10.2 & 16.1 & 0.0 & 7.3 & 19.3 & NA & NA & NA \\
\hline 2 & 21.9 & 40.2 & 72.2 & 7.9 & 14.8 & 31.7 & 6.8 & 14.8 & 34.0 & 3.1 & 17.6 & 74.0 & NA & NA & NA \\
\hline 3 & 1.8 & 23.8 & 51.4 & 1.4 & 10.5 & 18.1 & 4.7 & 10.5 & 18.4 & 0.0 & 7.6 & 19.4 & 0.0 & 7.7 & 15.6 \\
\hline 4 & 21.6 & 40.9 & 72.2 & 7.9 & 14.9 & 31.7 & 6.9 & 14.8 & 34.0 & 3.2 & 17.5 & 74.0 & 0.0 & 12.3 & 29.6 \\
\hline
\end{tabular}


Table 3 - Results of T-test per scenarios: $\mathrm{t}=\mathrm{t}$-value for T-test; g.l. = degrees of freedom; $\mathrm{p}=\mathrm{p}$-value for T-test; Effect $=$ effect of the scenarios; $\mathrm{N}=$ number of layers.

\begin{tabular}{|c|c|c|c|c|c|c|c|}
\hline \multicolumn{8}{|c|}{ Scenario 1 x Scenario 2} \\
\hline Layers & $\mathbf{t}$ & g.1. & $\mathbf{p}$ & $\begin{array}{c}\text { Mean } \\
\text { Scenario } 1\end{array}$ & $\begin{array}{c}\text { Mean } \\
\text { Senario } 2\end{array}$ & Effect & $\mathbf{N}$ \\
\hline Climatic stability areas & -3.962 & 22 & 0.001 & 0.233 & 0.402 & 1.727 & 23 \\
\hline Current models & -2.592 & 22 & 0.017 & 0.104 & 0.148 & 1.425 & 23 \\
\hline Future models & -2.888 & 22 & 0.009 & 0.102 & 0.148 & 1.450 & 23 \\
\hline Existing land cover change & -1.273 & 8 & 0.239 & 0.073 & 0.176 & 2.419 & 9 \\
\hline \multicolumn{8}{|c|}{ Scenario 3 x Scenario 4} \\
\hline Layers & $\mathbf{t}$ & g.1. & $\mathbf{p}$ & $\begin{array}{c}\text { Mean } \\
\text { Scenario } 3\end{array}$ & $\begin{array}{c}\text { Mean } \\
\text { Senario } 4\end{array}$ & Effect & $\mathbf{N}$ \\
\hline Climatic stability areas & -3.964 & 22 & 0.001 & 0.238 & 0.409 & 1.719 & 23 \\
\hline Current models & -2.558 & 22 & 0.018 & 0.105 & 0.149 & 1.419 & 23 \\
\hline Future models & -2.666 & 22 & 0.014 & 0.105 & 0.148 & 1.411 & 23 \\
\hline Existing land cover change & -1.225 & 8 & 0.255 & 0.075 & 0.175 & 2.317 & 9 \\
\hline Planned land cover change & -1.065 & 4 & 0.347 & 0.077 & 0.123 & 1.604 & 5 \\
\hline
\end{tabular}

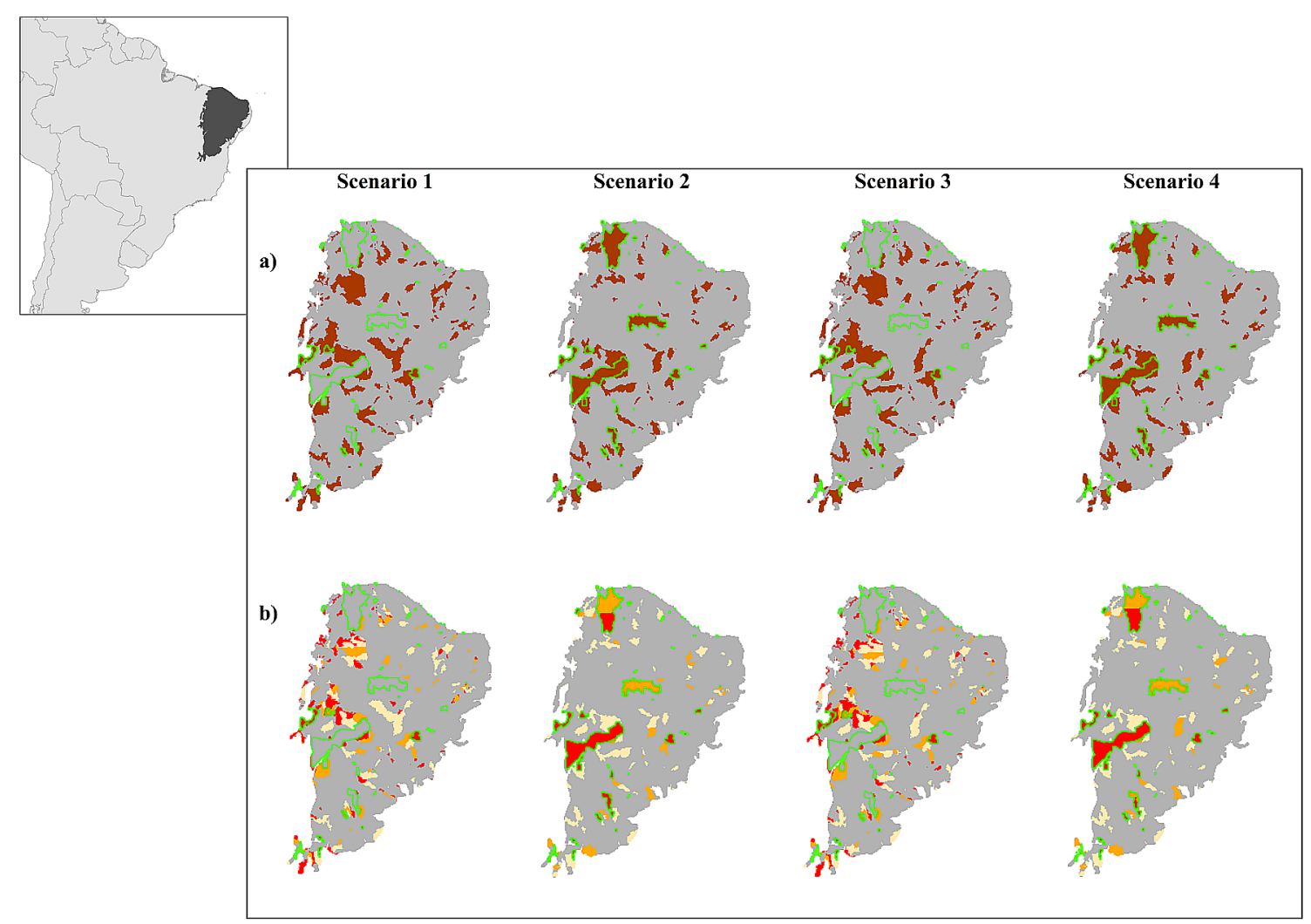

Figure 3 - Classification of the $17 \%$ of the planning units that presented higher conservation priority (brown pixels) (a); Classification with nested prioritization of planning units with the following bands: top $17 \%$ (yellow), top 10\% (orange) and top 5\% (red) (b). Limit of current protected areas in green. Scenario 1 (without removal mask and with existing cost), Scenario 2 (with removal mask and with existing cost), Scenario 3 (without removal mask and with existing and planned cost), Scenario 4 (with removal mask and with existing and planned cost). 


\section{Discussion}

The inclusion of the Caatinga's protected areas system, integrated with a set of priority areas, can maintain appropriate climatic conditions for the endangered birds in the face of the threats posed by climate and land cover changes. When existing protected areas are included in the solution, it is possible to protect a higher percentage of climate suitability.

Some studies evaluated the role of protected areas in the conservation of species in the face of climate change and reached similar conclusions. Araújo et al. (2011) analyzed the effectiveness of Europe's protected areas system in conserving plants and terrestrial animals under climate change. They concluded that the protected areas tend to maintain climate suitability for species better than a set of randomly selected unprotected areas.

Others studies show that current protected areas systems will not be able to support some taxa in a future climate change scenario. Virkkala et al. (2013) tested how efficient the system of protected areas in Finland is at preserving species of birds in three different climate scenarios. These authors used ecological niche models of 100 species of birds in four different environments, and they concluded that the Finnish protected areas system was inefficient to conserve forest species in the future. Unlike the system of protected areas of the Caatinga, which can assist in the conservation of endangered birds in the Caatinga according to our results.

Regardless of conclusions of some studies on the role of protected areas systems to maintain suitable climatic conditions for the persistence of taxa over time, most studies suggest that protected areas are an important part of a species conservation strategy in the face of climate change, in addition to other conservation strategies, such as establishing ecological corridors, restoration of degraded areas and the conservation of new areas (Araújo et al. 2011, Hannah et al. 2007, Virkkala et al. 2013). Our results emphasize that the climatic stability areas should be the focus of these actions because these areas offer adequate climatic conditions for taxa both under current and future climatic conditions. Thus, in spite of the uncertainties associated with future projections, the resources invested in those areas will not be wasted, since at least it will benefit the species that already inhabit them in the current climate situation.
Most conservation planning studies focus only on selecting areas based on the benefits to biodiversity. However, when executing a conservation plan ignoring the costs (land cover change), the opportunity to more efficiently achieve conservation objectives is lost (Naidoo et al. 2006). That is why we develop only scenarios that consider the costs involved. Although there is a greater number of land cover change in the solutions of the scenarios that include the existing protected areas, this did not result in reduced efficiency in the protection of target taxa because it was possible to protect a larger percentage of suitable areas, including climatic stability areas. At areas where conflicts between conservation and socioeconomic development goals already exists, such Environmental Protect Area of Lago de Sobradinho (state of Bahia, center of the biome), the government will need to adopt conservation actions aimed at conflict mediation and mitigation of environmental impacts since this area is part of the solution by containing the best sites for conservation of the threatened birds susceptible to climate change in the Caatinga.

Recently, Manhães et al. (2017) executed a selection of priority areas for conservation in Caatinga to determine two types of protected areas: sustainable use and strict protection. They analyzed changes in the protection of ecosystem services and the conservation of plant biodiversity upon excluding areas with high opportunity costs and high population density. However, the authors excluded the existing protected areas system of the Caatinga analysis. In this way, our work is complementary to them, since we analyzed the existing protected areas system of the Caatinga plus areas that should be complementary to it. Therefore, together, both works can give valuable subsidies on the establishment of protected areas for the Caatinga biome.

In summary, the existing protected areas system of the Caatinga, if integrated to a set of priority areas identified here, can maintain appropriate climatic conditions for endangered birds, even in the face of the challenges posed by climate and land cover changes. This reinforces the importance of protected areas systems as a national strategy for biodiversity conservation.

\section{Acknowledgement}

The authors would like to thank the Chico Mendes Institute for the granting to the first 
author of the paper financial support related to diaries and passages to attend the Postgraduate Program in Professional Masters Biodiversity in Conservation Units of the National School of Tropical Botany, located at Rio de Janeiro Botanical Garden. We would also like to thank Dr. Andrea Sanchez-Tápia for the inestimable help in developing and adapting the scripts and modeling functions in $\mathrm{R}$ environment, during the manuscript development. Finally, we would like to thank the staff from National Center for Research and Conservation of Wild Birds (CEMAVE) for helping with taxa information.

\section{References}

Araújo MB. 2009. Climate change and spatial conservation planning, p. 172-184. In: Moilanen A, Wilson KE, Possingham HP (eds.). Climate Change and Spatial Conservations Planning. Oxford University Press.

Araújo MB, Alagador D, Cabeza M, Nogués-Bravo $\mathrm{D}$, Thuiller W. Climate change threatens European conservation areas. Ecology Letters, 14(5): 484-492, 2011.

Araújo MB, New M. Ensemble forecasting of species distributions. Trends in Ecology \& Evolution, 22(1): 42-47, 2007.

Baselga A, Araújo MB. Individualistic vs community modelling of species distributions under climate change. Ecography, 32(1): 55-65, 2009.

Booth TH, Nix HA, Busby JR, Hutchinson MF. Bioclim: the first species distribution modelling package, its early applications and relevance to most current MaxEnt studies. Diversity and Distributions, 20(1): 1-9, 2014.

Breiman L. Random Forests. Machine Learning, 45(1): 5-32, 2001.

Carrol C, Dunk JR, Moilanen A. 2010. Optimizing resiliency of reserve networks to climate change: multispecies conservation planning in the Pacific Northwest, USA. Global Change Biology, 16(3): 891-904, 2010.

Cavalcanti IFA, Shimizu MH. Climate Fields over South America and Variability of SACZ and PSA in HadGEM2-ES. American Journal of Climate Change, 01(03): 132-144, 2012.

Cortes C, Vapnik V. Support-vector networks. Machine Learning, 20(3): 273-297, 1995.

Groves CR, Game ET, Anderson MG, Cross M, Enquist C, Ferdaña Z, Shafer SL. Incorporating climate change into systematic conservation planning. Biodiversity and Conservation, 21(7): 1651-1671, 2012.
Hannah L, Midgley G, Andelman S, Araújo M, Hughes G, Martinez-Meyer E, Williams P. Protected area needs in a changing climate. Frontiers in Ecology and the Environment, 5(3): 131-138, 2007.

Hijmans RJ, Phillips S, Leathwick J, Elith J. 2013. Dismo: Species distribution modeling. Vienna, Austria: The R Foundation for Statistical Computing. <https:// cran.r-project.org/web/packages/dismo/index.html>. Acesso em: 2015.

ICMBio (Instituto Chico Mendes de Conservação da Biodiversidade). 2014. Portaria n. 92, de 2 de setembro de 2014.

ICMBio (Instituto Chico Mendes de Conservação da Biodiversidade). 2018. Livro Vermelho da Fauna Brasileira Ameaçada de Extinção: Volume III - Aves. In: Instituto Chico Mendes de Conservação da Biodiversidade. (org.). Livro Vermelho da Fauna Brasileira Ameaçada de Extinção. ICMBio. 709p.

Keppel G, Van Niel KP, Wardell-Johnson GW, Yates CJ, Byrne M, Mucina L, Franklin SE. Refugia: identifying and understanding safe havens for biodiversity under climate change. Global Ecology and Biogeography, 21(4): 393-404, 2012.

Kujala H, Moilanen A, Araújo MB, Cabeza M, Williams P. Conservation Planning with Uncertain Climate Change Projections. PLoS ONE, 8(2): e53315, 2013.

Lemes P, Loyola RD, Possingham H, Butchart S, Collingham Y. Accommodating Species Climate-Forced Dispersal and Uncertainties in Spatial Conservation Planning. PLoS ONE, 8(1), e54323, 2013.

Liu C, White M, Newell G. Selecting thresholds for the prediction of species occurrence with presence-only data. Journal of Biogeography, 40: 778-789, 2013.

Madsen H, Thyregod P. 2011. Introduction to general and generalized linear models. CRC Press. <https:// books.google. com $\cdot$ br/books?hl=pt-BR\&lr $=\& \mathrm{id}=9 \mathrm{G}$ DNBQAAQBAJ\&oi $=$ fnd $\& p g=P P 1 \& d q=$ Introductio $\mathrm{n}+$ to + General + and + Generalized + Linear + Models \&ots $=$ AOlYwuUkCM\&sig $=$ EF1FUdEyc0iF9i3YGHC 5 pnac7CA\# $v=$ onepage\& $q=$ Introduction to General and Generalized Linear Models\&f $=$ false $>$. Acesso em: 2015.

Magrin GO, Marengo JA, Boulanger JP, Buckeridge MS, Castellanos E, Poveda G, Vicuña S. 2014. Central and South America, p. 1499-1566. In: Barros VR, Field CB, Dokken DJ, Mastrandrea MD, Mach KJ (eds.). Climate Change 2014: Impacts, Adaptation and Vulnerability. Cambridge University Press.

Mahalanobis PC. On the generalised distance in statistic. Proceedings National Institute of Science of India, 2(1): 49-55, 1936. 
Manhães AP, Loyola R, Mazzochini GG, Ganade G, Oliveira-Filho AT, Carvalho AR. Low-cost strategies for protecting ecosystem services and biodiversity. Biological Conservation, 217: 187-194, 2017.

Marengo JA, Bernasconi M. Regional differences in aridity/drought conditions over Northeast Brazil: present state and future projections. Climatic Change, 129 (1-2): 103-115, 2015.

Margules CR, Pressey RL. Systematic conservation planning. Nature, 405(6783): 243-253, 2000.

MMA (Ministério do Meio Ambiente). 2002. Caatinga. In: Avaliação e identificação de áreas e ações prioritárias para a conservação, utilização sustentável e repartição dos benefícios da biodiversidade nos biomas brasileiros. MMA/SBF. 404p. < http://www.mma.gov.br/estruturas/ chm/_arquivos/biodivbr.pdf>. Acesso em: 2015.

MMA (Ministério do Meio Ambiente). 2011. Monitoramento do desmatamento nos biomas brasileiros por satélite. <http://www.mma.gov.br/ estruturas/sbf_chm_rbbio/_arquivos/relatorio_tecnico_

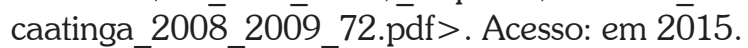

MMA (Ministério do Meio Ambiente). 2014a. Portaria n. 444, de 17 de dezembro de 2014. Diário Oficial da União.

MMA (Ministério do Meio Ambiente). 2014b. Portaria n. 445, de 17 de dezembro de 2014. Diário Oficial da União.

Moilanen A, Franco AM, Early RI, Fox R, Wintle B, Thomas CD. Prioritizing multiple-use landscapes for conservation: methods for large multi-species planning problems. Proceedings of the Royal Society of London: Biological Sciences, 272(1575), 2005.

Moilanen A, Pouzols FM, Laura M, Victoria V, Arponen A, Leppanen J, Kujala H. 2014. Spatial conservation planning methods and software - ZONATION - Version 4 User Manual. Helsinki: University of Helsinki, Finland. $<$ http://cbig.it.helsinki.fi>. Acesso em: 2015.

Naidoo $\mathrm{R}$, et al. Integrating economic costs into conservation planning. Trends in Ecology \& Evolution, 21(12): 681-687, 2006.

Nenzén HK, Araújo MB. Choice of threshold alters projections of species range shifts under climate change. Ecological Modelling, 222(18): 3346-3354, 2011.

Oyama MD, Nobre CA. A new climate-vegetation equilibrium state for Tropical South America. Geophysical Research Letters, 30(23): 2003.

Parmesan C, Yohe G. A globally coherent fingerprint of climate change impacts across natural systems. Nature, 421(6918): 37-42, 2003.
Pearson RG, Dawson TP. Predicting the impacts of climate change on the distribution of species: are bioclimate envelope models useful? Global Ecology and Biogeography, 12(5): 361-371, 2003.

Pfafstetter O. 2012. Bacias Hidrográficas Ottocodificadas (Níveis Otto). Agência Nacional de Águas. <http://metadados.ana.gov.br/geonetwork/srv/ $\mathrm{pt} /$ main . home?uuid =b228d007-6d68-46e5-b30da1e191b2b21f > . Acesso em: 2015.

Phillips SJ, Anderson RP, Schapire RE. Maximum entropy modeling of species geographic distributions. Ecological Modelling, 190(3): 231-259, 2006.

R Core Team. R: A language and environment for statistical computing. R Foundation for Statistical Computing. <https://www.r-project.org/> (Acesso em 2015).

Rao, C. R. 1973. Prasantha Chandra Mahalanobis. 1893-1972. Biographical Memoirs of Fellows of the Royal Society, 19: 454492, 2015.

Root TL, et al. Fingerprints of global warming on wild animals and plants. Nature, 421(6918): 57-60, 2003.

Silva JMC, Souza MA, Bieber AGD, Carlos CJ. 2003. Aves da Caatinga: Status, uso do habitat e sensitividade. In: Leal IR, Tabarelli M, Silva JMC (eds.). Ecologia e conservação da caatinga. Universitária da UFPE. $822 \mathrm{p}$.

Silveira CS, Filho FAS, Costa AA, Cabral AL. Avaliação de desempenho dos modelos do CMIP5 quanto à representação dos padrões de variação da precipitação no século XX sobre a região nordeste do Brasil, Amazônia e bacia do Prata e análise das projeções para o cenário RCP8.5. Revista Brasileira de Meteorologia, 28(3): 317-330, 2013.

Tabarelli M, Silva JMC. 2003. Áreas e ações prioritárias para a conservação da biodiversidade da Caatinga. In: Leal IR, M. Tabarelli, Silva JMC (eds.). Ecologia e conservação da caatinga. Universitária da UFPE. $822 \mathrm{p}$.

Virkkala R, Heikkinen RK, Fronzek S, Leikola N, Nelson K. Climate Change, Northern Birds of Conservation Concern and Matching the Hotspots of Habitat Suitability with the Reserve Network. PLoS ONE, 8(5): e63376, 2013.

Wiens JJ, Graham $\mathrm{CH}$. Niche Conservatism: Integrating Evolution, Ecology, and Conservation Biology. Annual Review of Ecology, Evolution, and Systematics, 36(1): 519-539, 2005.

Zhang L, Liu S, Sun P, Wang T, Wang G, Zhang X, Wang L. Consensus Forecasting of Species Distributions: The Effects of Niche Model Performance and Niche Properties. PLOS ONE, 10(3): e0120056, 2015. 


\section{Supplementary Material}

Table 1 - Bird species used for modeling analysis and threatened status determination.

\begin{tabular}{|c|c|c|c|}
\hline Taxon & Acronym & Category of threat & Number of unique records \\
\hline Anodorhynchus leari & an_le & EN & 145 \\
\hline Antilophia bokermanni & an_bo & $\mathrm{CR}$ & 23 \\
\hline Augastes lumachella & au_lu & EN & 45 \\
\hline Conopophaga lineata cearae & co_li_ce & EN & 43 \\
\hline Crypturellus noctivagus zabele & Cr_no_za & VU & 58 \\
\hline Cyanopsitta spixii & $c y \_s p$ & $\mathrm{CR}(\mathrm{PEW})$ & 10 \\
\hline Formicivora grantsaui & fo_gr & $\mathrm{EN}$ & 15 \\
\hline Hemitriccus mirandae & he_mi & VU & 45 \\
\hline Lepidocolaptes wagleri & le_wa & $\mathrm{EN}$ & 40 \\
\hline Neomorphus geoffroyi geoffroyi & ne_ge_ge & $\mathrm{CR}(\mathrm{PEX})$ & 3 \\
\hline Penelope jacucaca & pe ja & VU & 114 \\
\hline Phylloscartes beckeri & ph_be & EN & 26 \\
\hline Phylloscartes roquettei & ph_ro & EN & 45 \\
\hline Pyrrhura griseipectus & py_gr & $\mathrm{EN}$ & 21 \\
\hline Sclerurus cearensis & sc_ce & VU & 32 \\
\hline Scytalopus diamantinensis & $s c_{-} d i$ & EN & 13 \\
\hline Selenidera gouldii baturitensis & se_go_ba & $\mathrm{EN}$ & 3 \\
\hline Sporagra yarrellii & sp_ya & VU & 103 \\
\hline Tangara cyanocephala cearensis & ta_cy_ce & VU & 7 \\
\hline Thamnophilus caerulescens cearensis & th_ca_ce & VU & 9 \\
\hline Xiphocolaptes falcirostris & $x i f a$ & VU & 96 \\
\hline Xiphorhynchus atlanticus & xi_at & VU & 63 \\
\hline Xiphorhynchus guttatus gracilirostris & xi_gu_gr & EN & 6 \\
\hline Total & & & 965 \\
\hline
\end{tabular}


Figure 1 - Present and future ecological niche models of 23 endangered bird species. Higher values indicate more climatically adequated areas.

Antilophia bokermanni

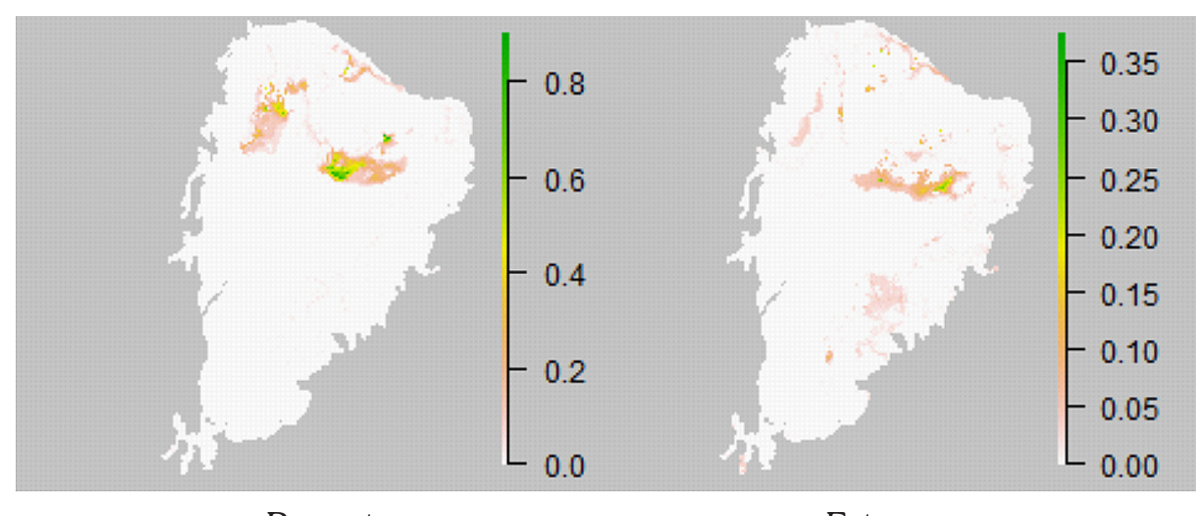

Present

Future

Anodorhynchus leari

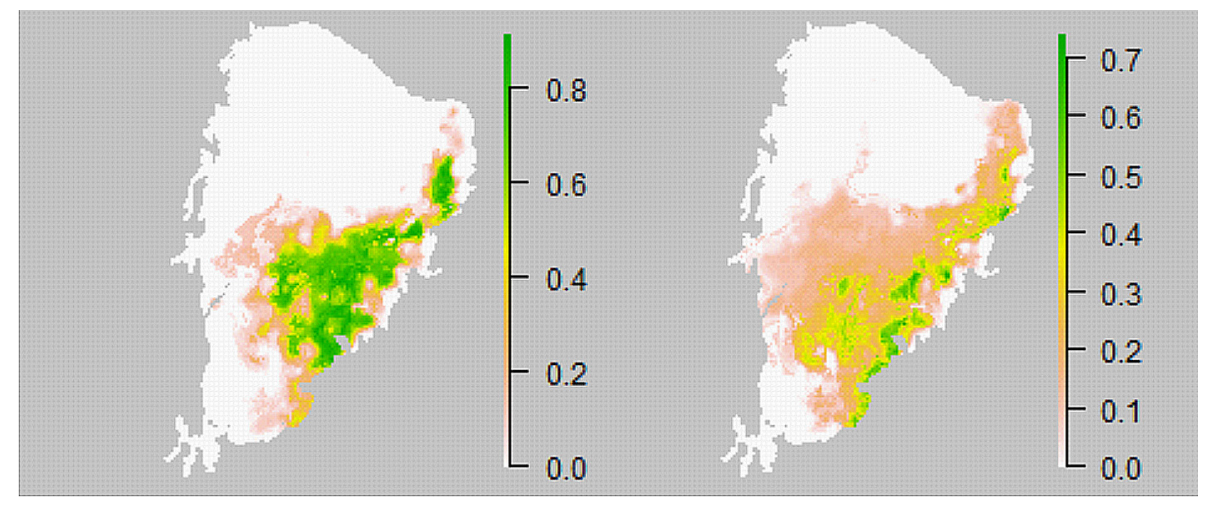

Present

Future

Augastes lumachella

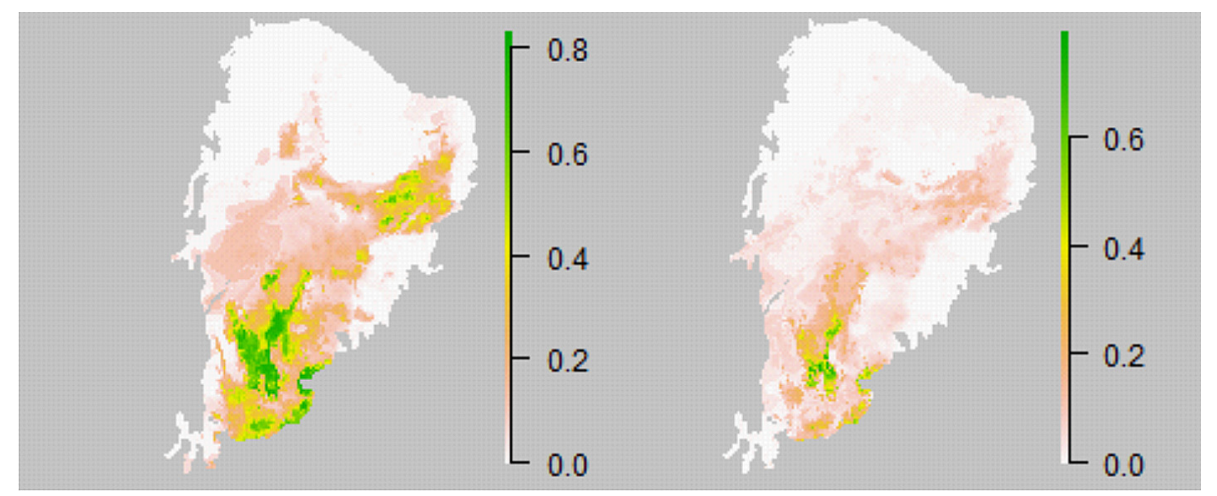

Present

Future 


\section{Conopophaga lineata cearae}

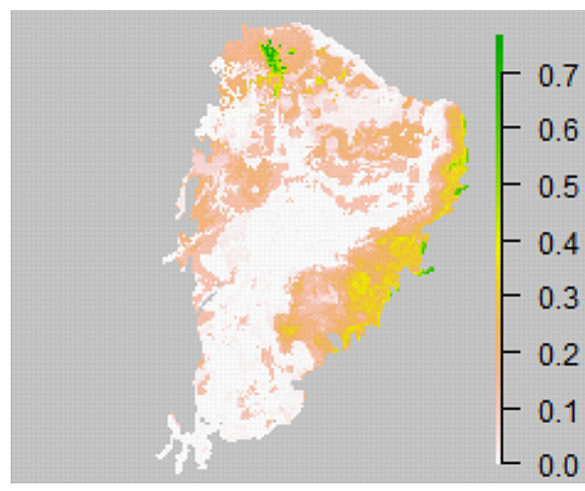

Present

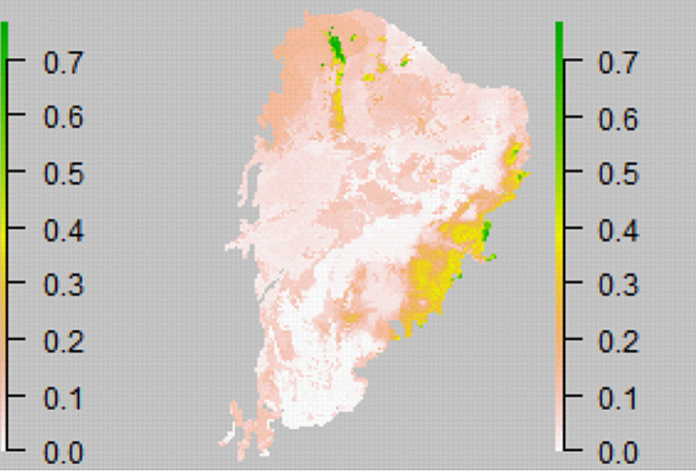

Future

Crypturellus noctivagus zabele

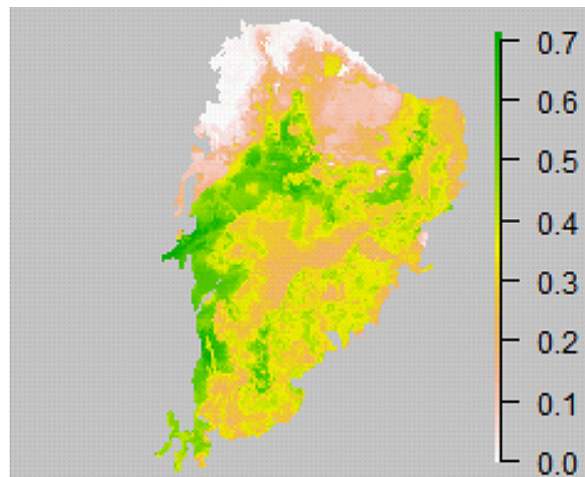

Present

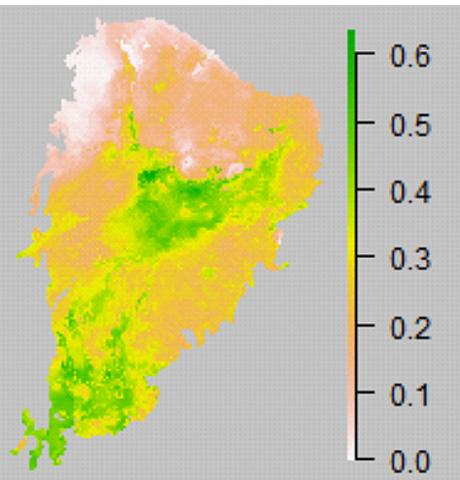

Future

\section{Cyanopsitta spixii}

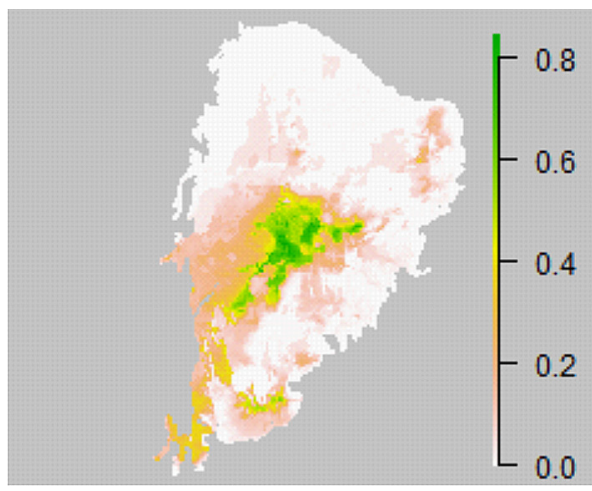

Present

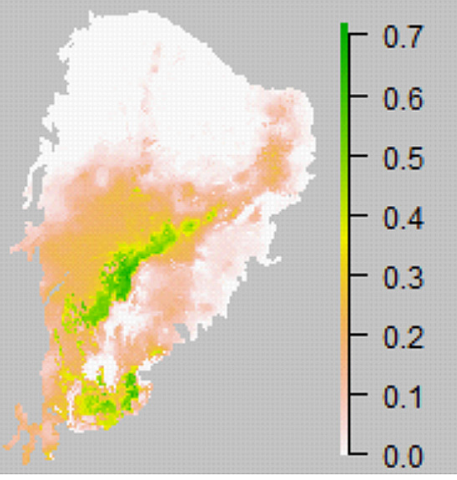

Future 


\section{Formicivora grantsaui}

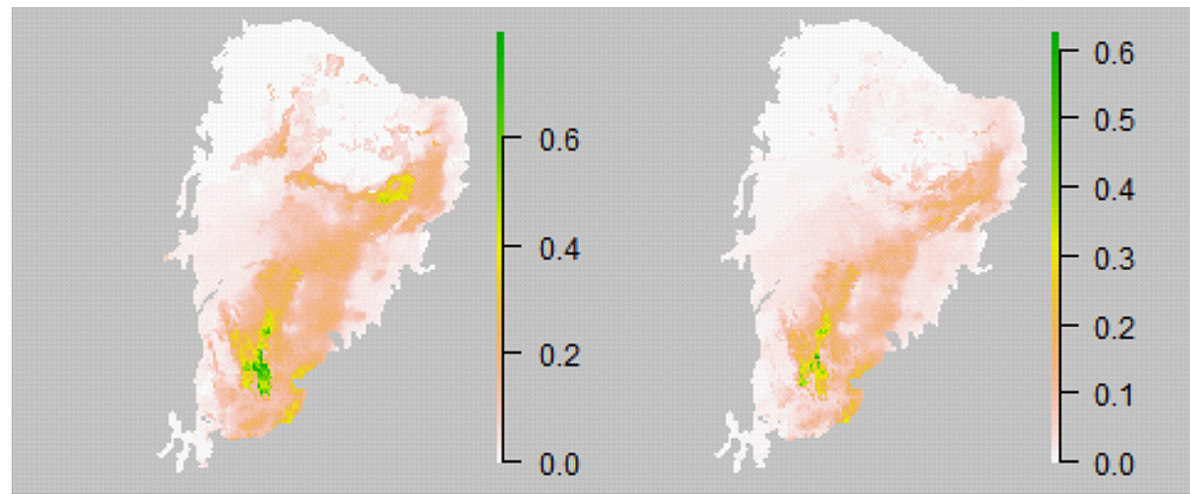

Present

Future

Hemitriccus mirandae

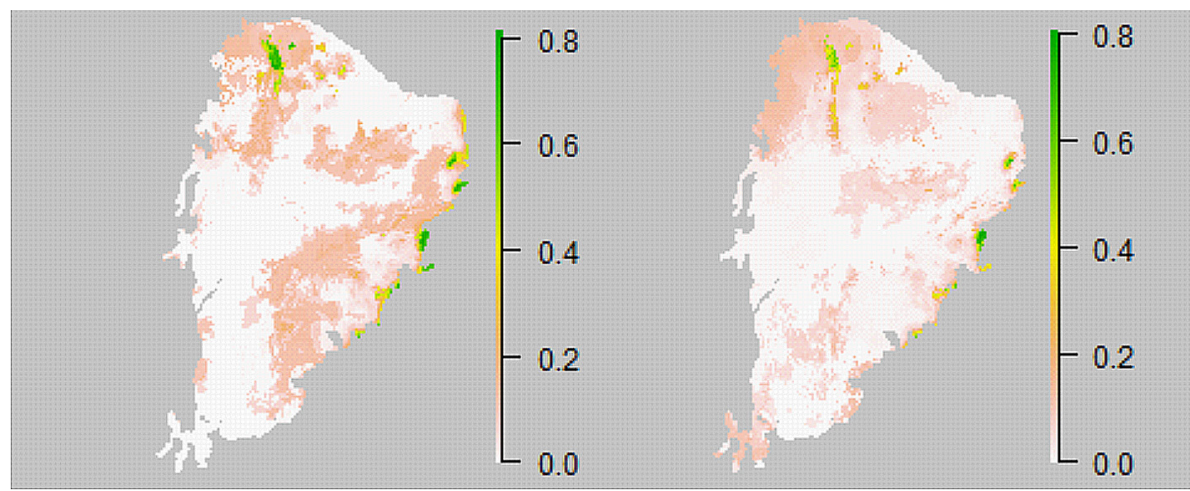

Present

Future

\section{Lepidocolaptes wagleri}

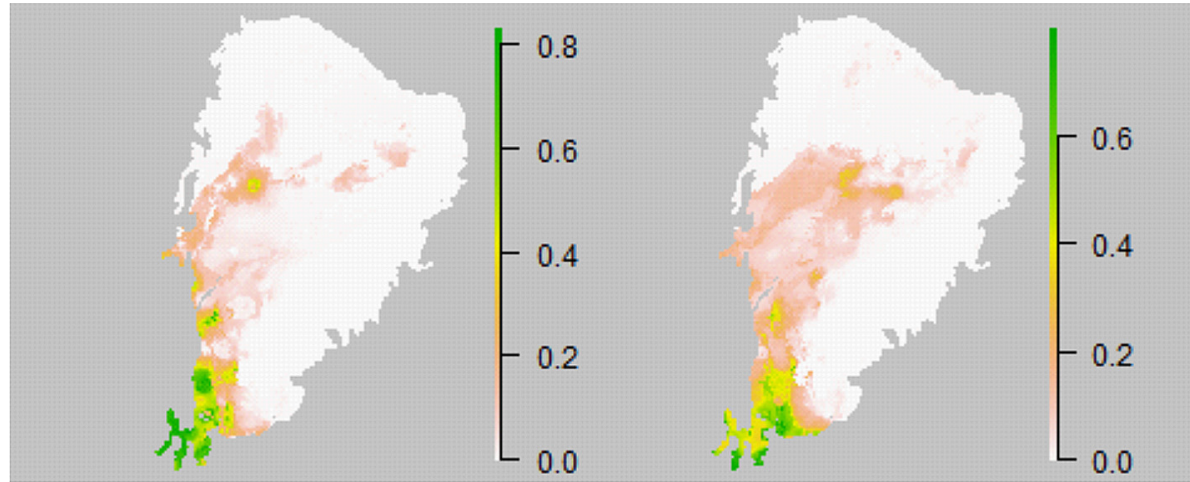

Present

Future 


\section{Lepidocolaptes wagleri}

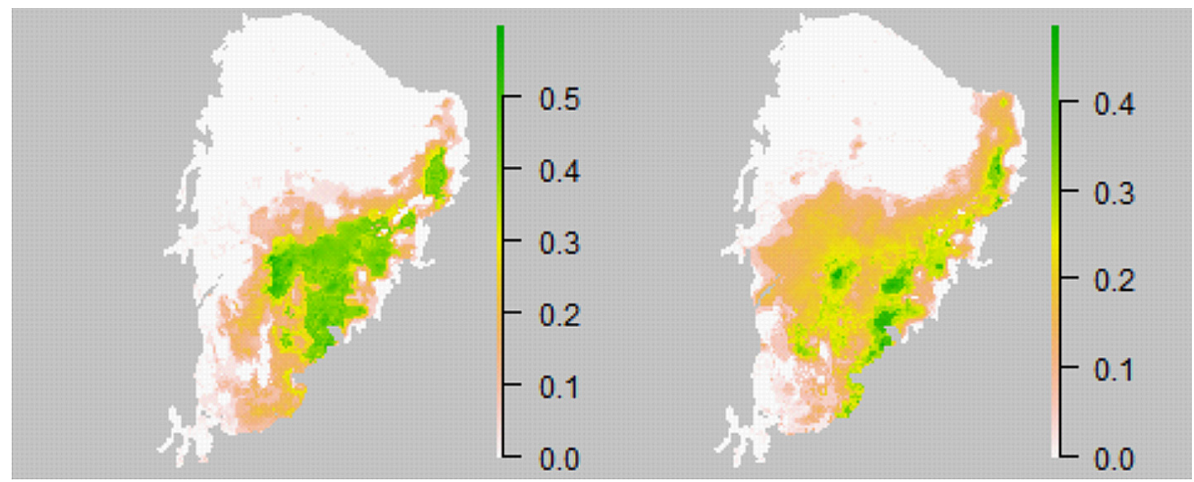

Present

Future

\section{Neomorphus geoffroyi geoffroyi}

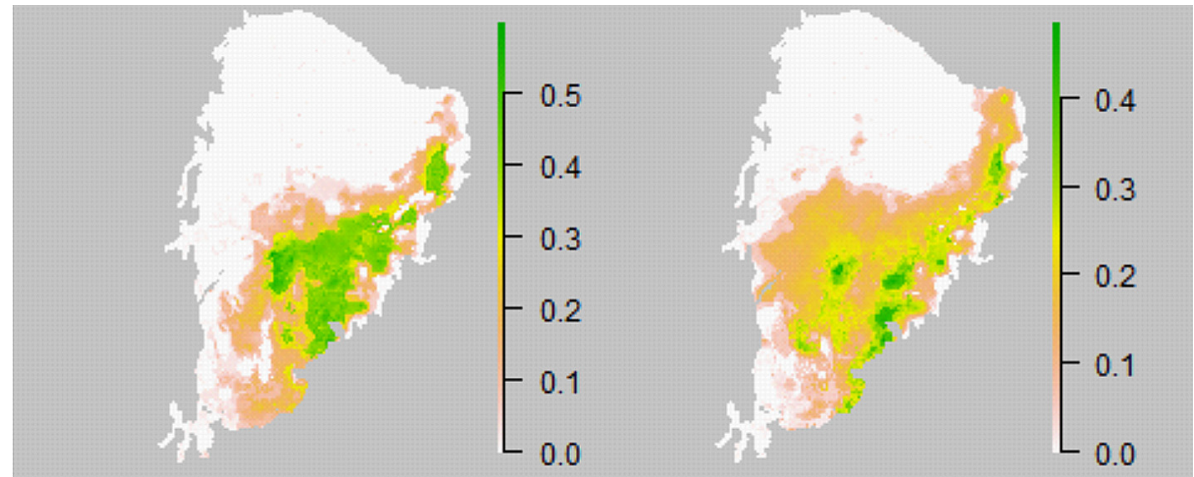

Present

Future

Penelope jacucaca

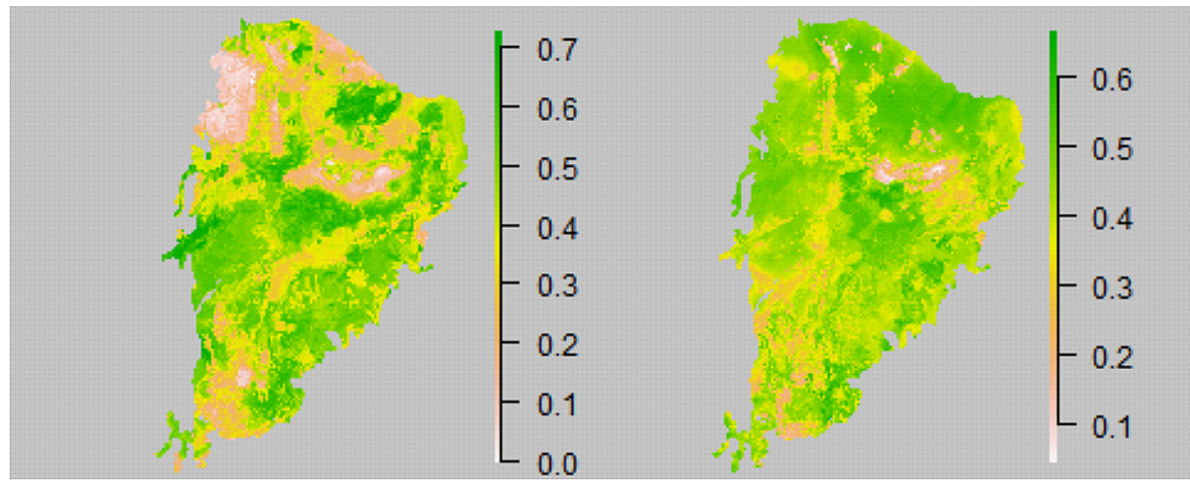

Present

Future 


\section{Phylloscartes beckeri}

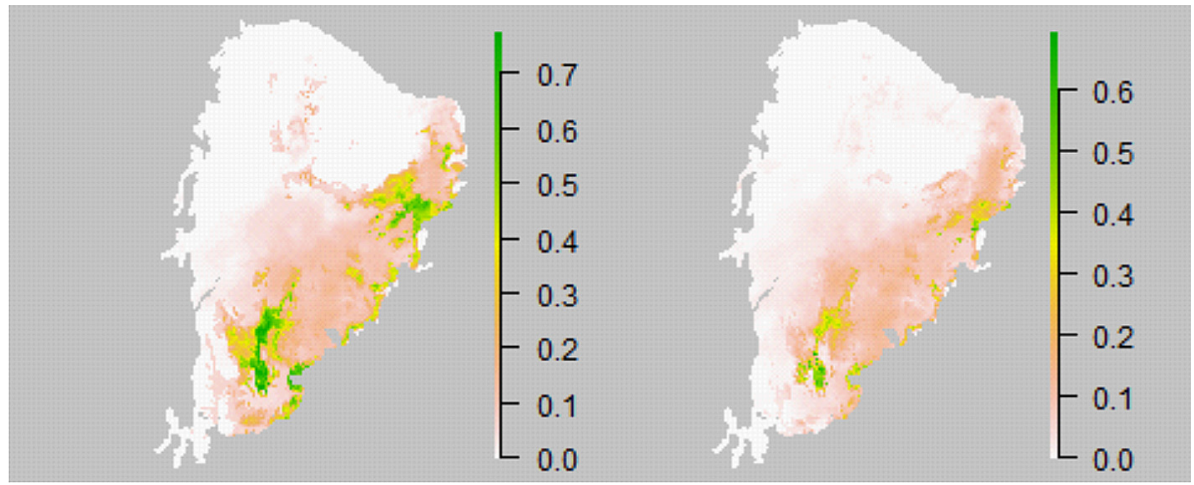

Present

Future

\section{Phylloscartes roquettei}

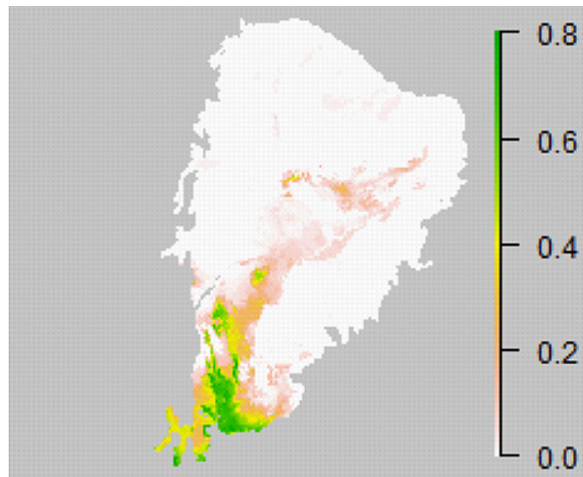

Present

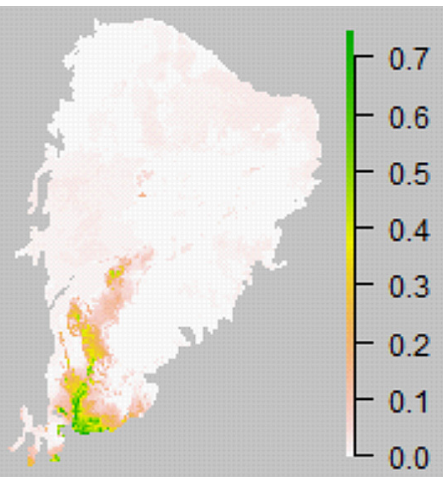

Future

Pyrrhura griseipectus

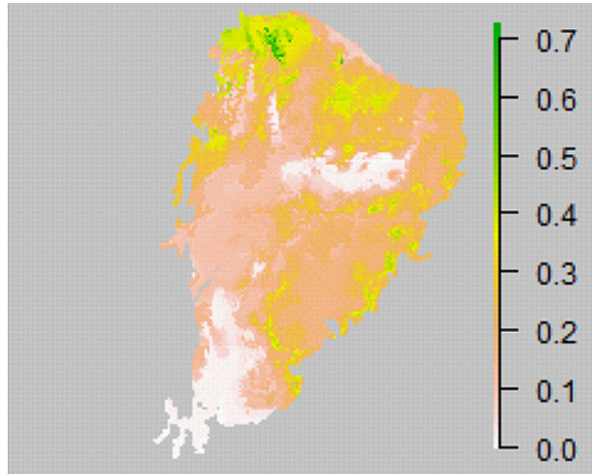

Present

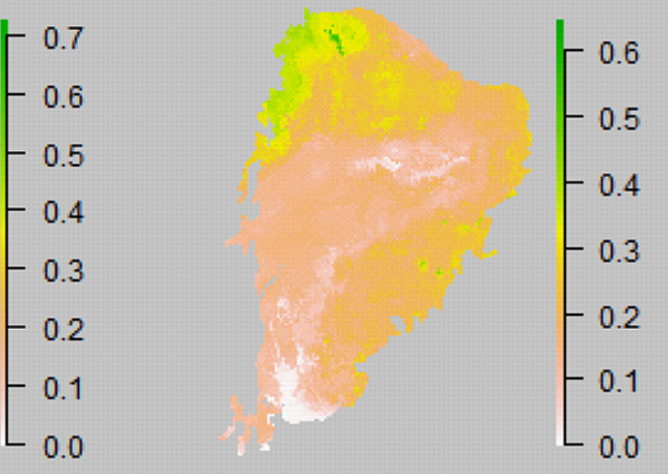

Future 
Sclerurus cearensis

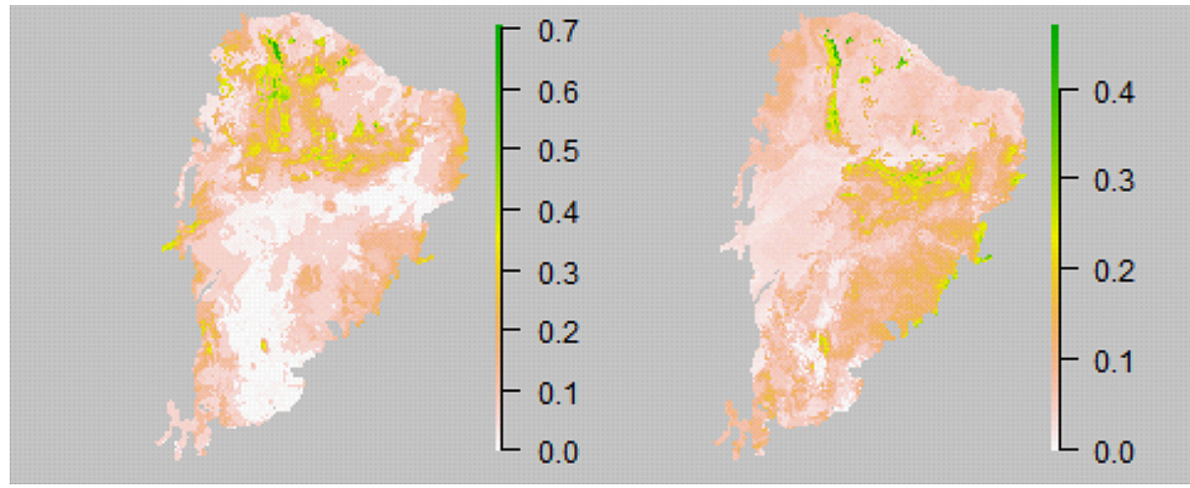

Present

Future

Scytalopus diamantinensis

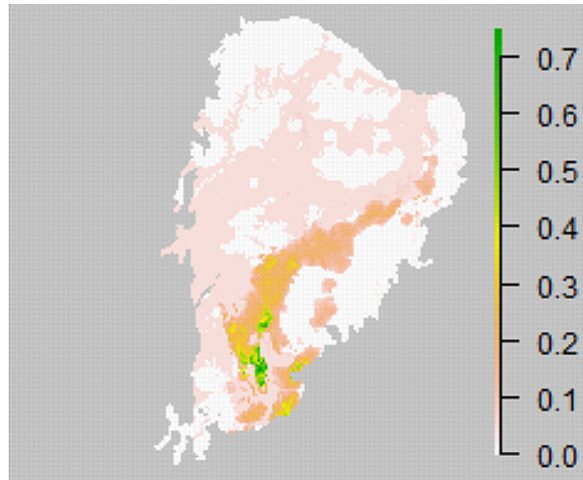

Present

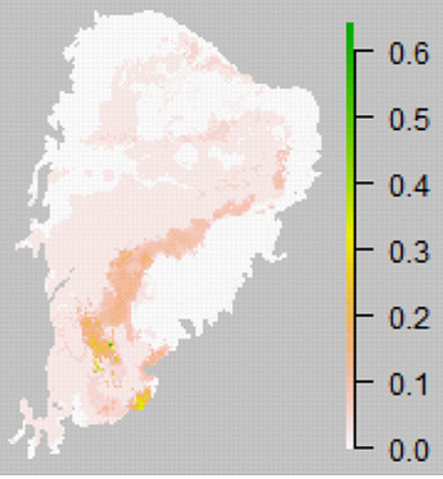

Future

Selenidera gouldii baturitensis

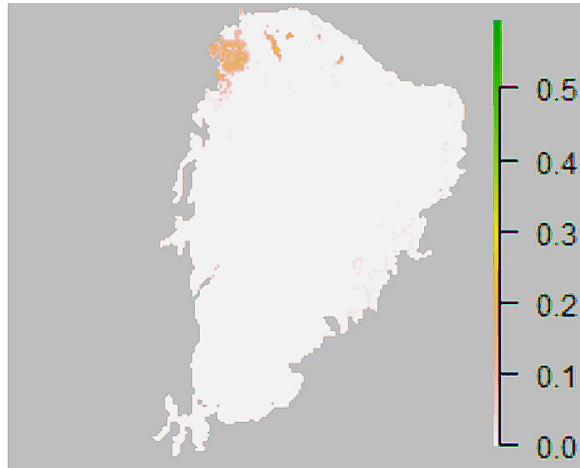

Present

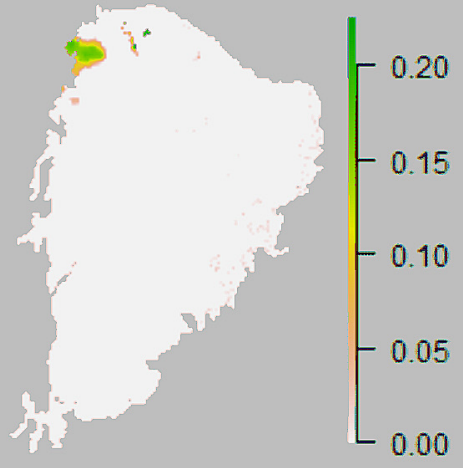

Future 


\section{Sporagra yarrellii}

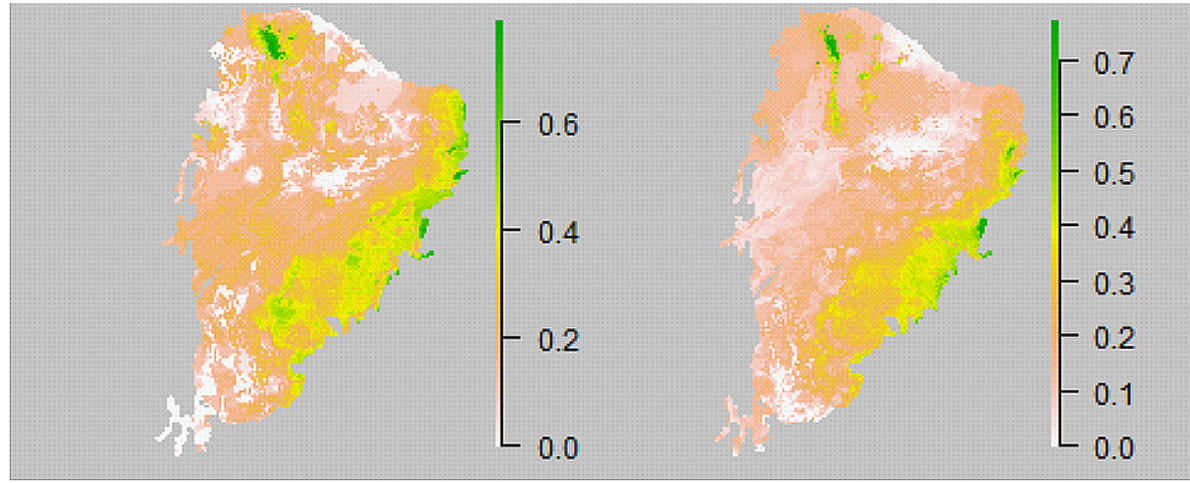

Present

Future

Tangara cyanocephala cearenses

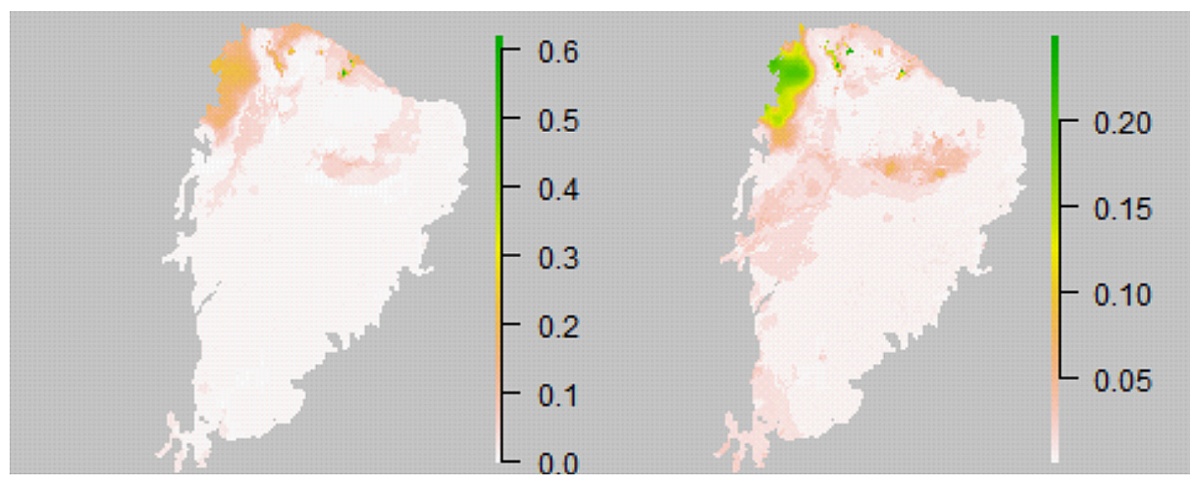

Present

Future

Thamnophilus caerulescens cearenses

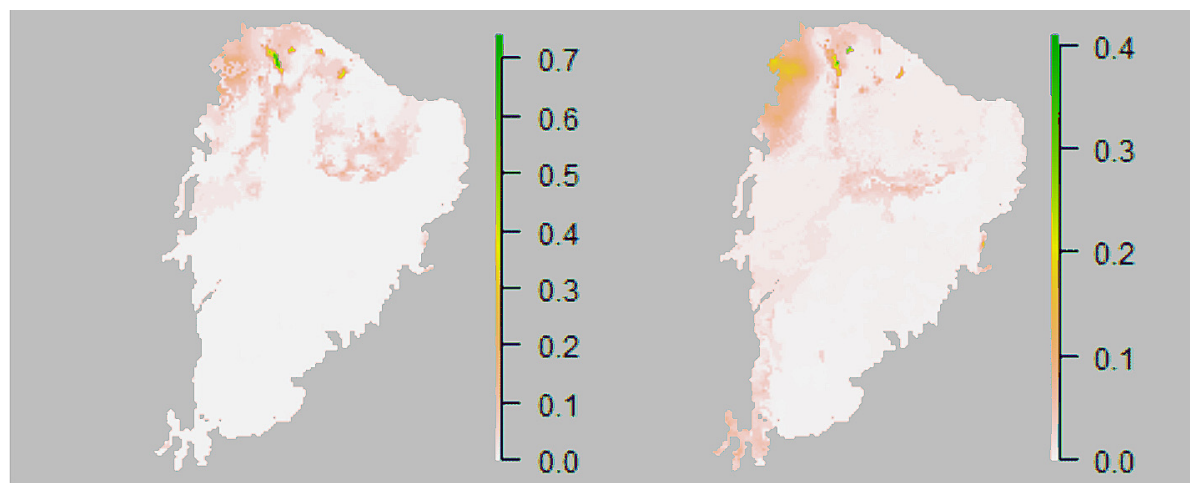

Present

Future 


\section{Xiphorhynchus atlanticus}

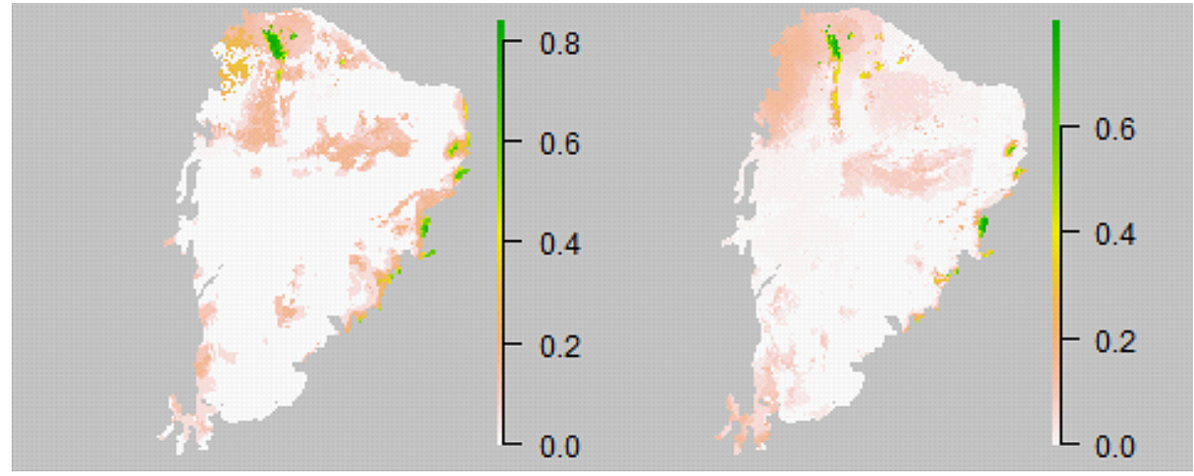

Present

Future

\section{Xiphocolaptes falcirostris}

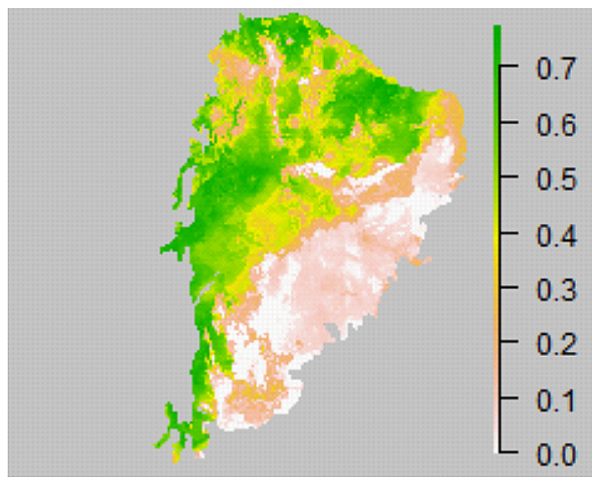

Present

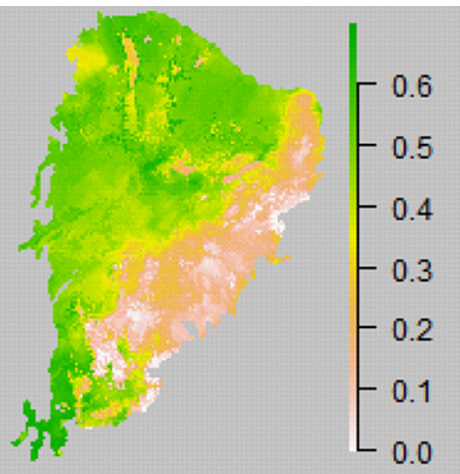

Future

Xiphorhynchus guttatus gracilirostris

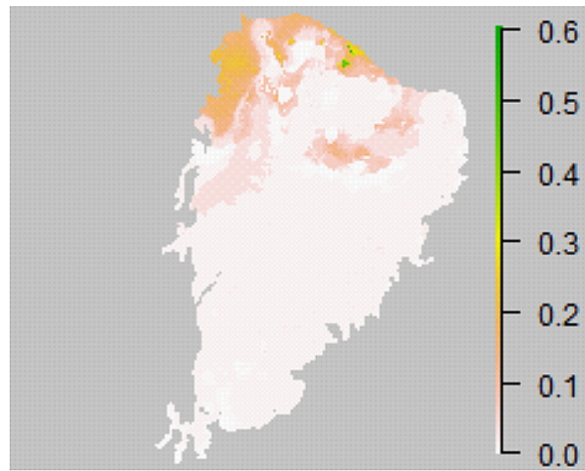

Present

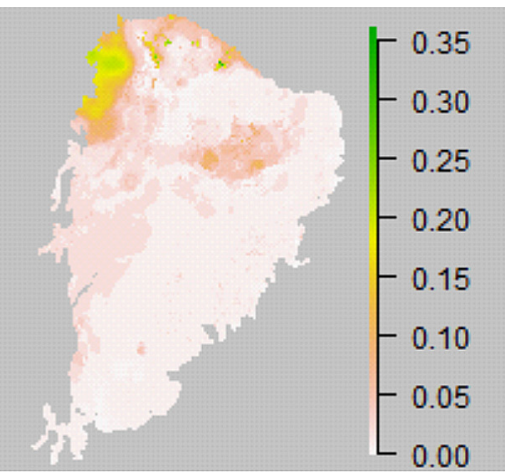

Future 
Biodiversidade Brasileira - BioBrasil.

Edição temática: Diálogos entre a Academia e a Gestão de Áreas Protegidas:

Programa de Pós-Graduação Profissional - Biodiversidade em Unidades de Conservação

n. 2, 2020

http://www.icmbio.gov.br/revistaeletronica/index.php/BioBR

Biodiversidade Brasileira é uma publicação eletrônica científica do Instituto Chico Mendes de Conservação da Biodiversidade (ICMBio) que tem como objetivo fomentar a discussão e a disseminação de experiências em conservação e manejo, com foco em unidades de conservação $e$ espécies ameaçadas.

ISSN: 2236-2886 